Portland State University

PDXScholar

Civil and Environmental Engineering

Undergraduate Honors Theses

Spring 2017

\title{
Emerging Pollutants in the Columbia River: a Simple Assessment of Nonpoint Source Zones
}

Chulgi Kim

Portland State University

Follow this and additional works at: https://pdxscholar.library.pdx.edu/cengin_honorstheses

Part of the Civil and Environmental Engineering Commons

Let us know how access to this document benefits you.

\section{Recommended Citation}

Kim, Chulgi, "Emerging Pollutants in the Columbia River: a Simple Assessment of Nonpoint Source Zones" (2017). Civil and Environmental Engineering Undergraduate Honors Theses. 6.

https://doi.org/10.15760/honors.461

This Thesis is brought to you for free and open access. It has been accepted for inclusion in Civil and Environmental Engineering Undergraduate Honors Theses by an authorized administrator of PDXScholar. Please contact us if we can make this document more accessible: pdxscholar@pdx.edu. 


\title{
Emerging Pollutants in the Columbia River:
}

\section{A Simple Assessment of Nonpoint Source Zones}

\author{
Chulgi Kim \\ Portland State University \\ Civil and Environmental Engineering Department
}

Adviser: Gwynn R. Johnson, Ph.D.

Portland State University

Department of Civil and Environmental Engineering 


\section{Acknowledgements}

I would like to thank the Civil and Environmental Engineering Department for giving me this opportunity. Thank you to Dr. Gwynn Johnson, for her advices and guidance. I was able to finish this thesis because of her help. Thank you to Ariel Lewis, department manager for consistently caring about my honors program. I was able to meet Dr. Gwynn Johnson as an adviser through her for the honors program.

I also want to thank Sue Han, my fiancé for her encouragement and love. She always supports me to go forward in the right direction. Through her devotion for me, I have overcome many difficulties. I want to say again that I love Sue.

Thank my parents for their commitment to me. They are always on my side and always do their best for me. I am here and happy because of them. I would like to say that I really love and appreciate them.

Finally, above all, I thank God. Through His grace, I am able to do all things. I give all the glory to God. 


\begin{abstract}
Water quality modeling in the Columbia River Basin was conducted at the confluence of the Willamette and Columbia Rivers, river mile 101. The study area for this research consists of Sauvie Island, OR, and the surrounding areas of Vancouver, WA. Analysis of the region's watershed and simple hydrologic calculations allowed for estimates of potential sources contributing to PBDEs in the Columbia River along river mile 101. This research included assessment of rainfall patterns and peak discharge rates in the areas along the rivers. A simple model of overland flow for the watershed was applied to estimate the area's contribution to overall flow in the Columbia River. Potential impacts and possible sources for emerging pollutants in the Columbia River at river mile 101 were inferred from this analysis.
\end{abstract}




\section{List of Figures}

Figure 1 Decadal trends and projections in Columbia River Basin population size, 1930-2030.

(Independent Scientific Advisory Board, 2007)

Figure 2 Toxic contaminant pathways in the environment (EPA, 2009)

Figure 3 PBDE levels, measured in blood serum and expressed on a lipid weight basis. $\longrightarrow$ P. 10

(Washington Toxics Coalition, 2006)

Figure 4 Contaminant concentrations (nanograms per gram, wet weight) in fish tissue composites $-\mathbf{P} .11$

for the three sites from 2009 collection. Error bars based on reported \%RSD values. (Nilsen et al., 2014)

Figure 1 Total PBDEs in biological samples on the lower Columbia River (GSI Water Solution Inc., 2011) - P. 12

Figure 6 Sampling site locations in the lower Columbia River and selected tributaries (Nilsen et al., 2007) - P. 13

Figure 7 Sauvie Island soil map $\longrightarrow$ P. 14

(West Multnomah Soil and Water Conservation District, 2014)

Figure 8 Topographic map of the location of interest from ArcGIS $\longrightarrow$ P. 14

Figure 9 Aerial photograph of the location on interest from Google maps $\longrightarrow$ P. 14

Figure 10 Topographic map for the directions of water flow and gradients $\longrightarrow$ P. 15

Figure 11 The directions of water flow and gradients of Section A, B, and C $\longrightarrow$ P. 16

Figure 12 The direction of water flow and gradient of Section D $\longrightarrow$ P. 16

Figure 13 The estimated areas potentially affecting water quality of the Columbia River along river mile 101

(from ArcGIS maps) — P. 17

Figure 14 Topographic Map for Section D $\longrightarrow$ P. 20

\section{List of Tables}

Table 1 Site names, percent organic carbon, and locations (Nilsen et al., 2007)

Table 2 Frequency analysis of different duration of precipitation depths $\longrightarrow$ P. 19

Table 3 Intensity of duration at 2-year return period. $\quad \longrightarrow$ P. 20

Table 4 Peak Discharge Rate Estimates — P. 22 


\section{Contents}

$\begin{array}{lr}\text { 1. Introduction } & \text { P. } 6\end{array}$

1.1 The Columbia River $\quad$ P. 6

1.2 Population Trend and Effect in The Columbia River Basin $\quad$ P. 6

$\begin{array}{ll}1.3 \text { Toxic Contaminants } & \text { P. } 7\end{array}$

1.4 Contaminants of Concern in the Columbia River Basin $\quad$ P. 8

$\begin{array}{ll}1.5 \text { Polybrominated Diphenyl Ethers } & \text { P. } 9\end{array}$

$\begin{array}{lr}\text { 2. Survey } & \text { P. } 10\end{array}$

2.1 Indicator $\quad$ P. 10

2.2 Biological Samples Used for the Survey $\quad$ P. 11

$\begin{array}{ll}\text { 3. Analysis of the Site of Interest } & \text { P. } 12\end{array}$

3.1 Site Selection for Water Quality Modeling $\quad$ P. 12

$\begin{array}{ll}3.2 \text { Characteristics of the location of Interest } & \text { P. } 13\end{array}$

$\begin{array}{lr}\text { 4. Hydrologic Calculations for Water Quality Modeling } & \text { P. } 18\end{array}$

4.1 Intensity-Duration-Frequency (IDF) curve of 2-year Return Period $\quad$ P. 18

4.2 Time of concentration and Magnitude of the 2-year Storm $\quad$ P. 21

$\begin{array}{ll}\text { 5. Water Quality Modeling } & \text { P. } 22\end{array}$

5.1 Analysis of the Data $\quad$ P. 22

5.2 Simple Assessment of Overland Flow and Potential Impacts $\quad$ P. 23

$\begin{array}{ll}\text { 6. Conclusion } & \text { P. } 24\end{array}$

\begin{tabular}{ll} 
7. Reference & P. 26 \\
\hline
\end{tabular} 


\section{Introduction}

\subsection{The Columbia River}

The Columbia River is one of the largest rivers in the world with regard to its volume and basin. The Columbia River Basin is approximately 259,000 square miles, and covers seven states and provinces in the United States and British Columbia, Canada (EPA, 2009). The approximately 8 million people who live in the basin acquire many resources from the Columbia River Basin (EPA, 2009). According to the Washington State Department of Ecology (2017), the average annual flow of the River in the Dalles, Oregon, is approximately 190,000 cubic feet per second (cfs). In addition, the range of the river's annual discharge rate ranges from 120,000 cfs to $260,000 \mathrm{cfs}$, and the annual amount of used water quantity from the river for agriculture is approximately 325,851 gallons (Washington State Department of Ecology, 2017). The Columbia Basin Research in School of Aquatic and Fishery Sciences (2017) states that there are 19 hydroelectric dams in the Columbia River Basin total which consist of 11 federal dams and 8 non-federal dams. Due to the greatness of the river, the Columbia River closely interacts with adjacent basins, and plays an important role for surrounding environments as one of the most important source of resources.

\subsection{Population Trend and Effect in the Columbia River Basin}

There has been an increase in population in the Columbia River Basin in four states of the United States and the province of British Columbia since 1930. This growth is proceeding rapidly, and the trend is expected to continue until 2030 (Independent Scientific Advisory Board, 2007; see Figure 1). This rapid change of population results in urbanization and industrialization. Finally, the result of the change can affect the ecosystem in the basin, and cause environmental 
problems. Population growth fundamentally causes more consumption for area, water, and hydroelectricity. This consumption imposes a significant burden on the environmental system.

The environmental burden causes negative physical, chemical, and ecological effects on the river ecosystems. These effects generally result in environmentally fatal problems (Independent Scientific Advisory Board, 2007).

\subsection{Toxic Contaminants}

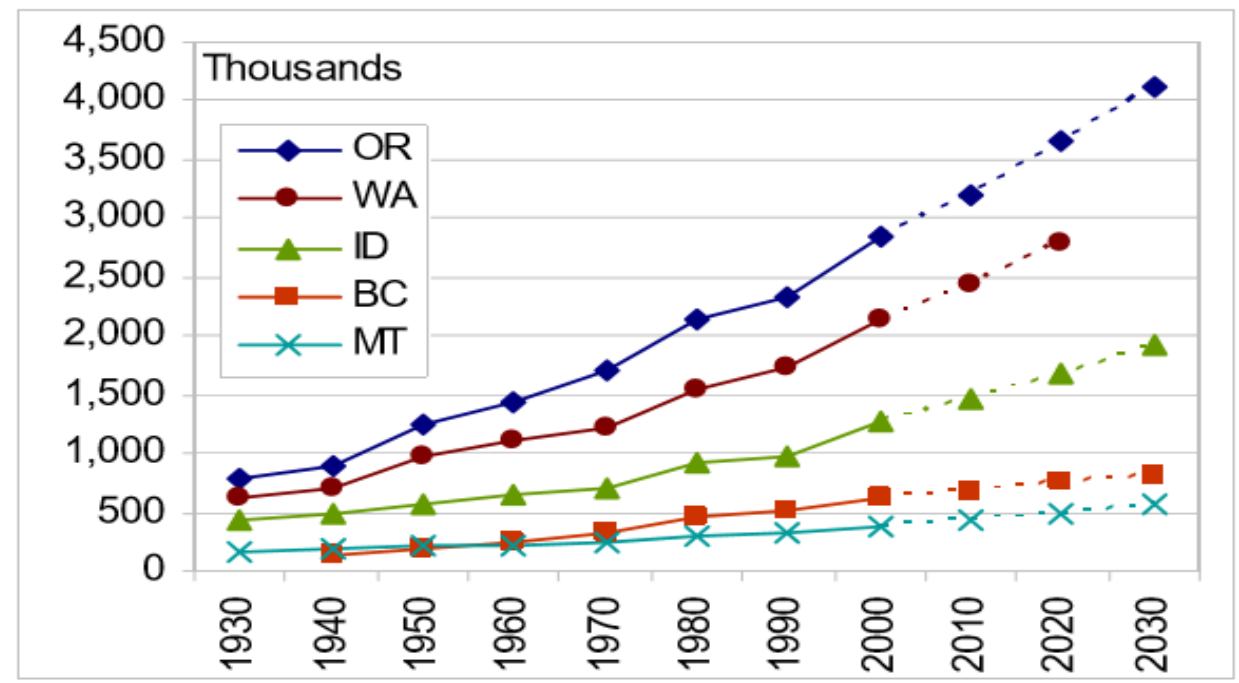

Figure 1 Decadal trends and projections in Columbia River Basin population size, 1930-2030. (Independent Scientific Advisory Board, 2007)

Toxic contaminants are chemicals introduced to the environment in amounts that can be harmful to fish, wildlife, or people. Some chemicals exist in the environment for a long period of time. These contaminants are called persistent contaminants; and well-known pollutants are DDT, mercury, and PCBs. The toxins are accumulated in the bottom of the river basin, which are then absorbed by submerged vegetation and animals such as plankton (EPA, 2009). Through the food web (see Figure 2), this contamination is diffused to the entire ecosystem. Currently, toxic contaminants are threatening the lives of the ecosystem. These toxins have become a significant problem, and many researches are conducted to find solutions scientifically and politically. 


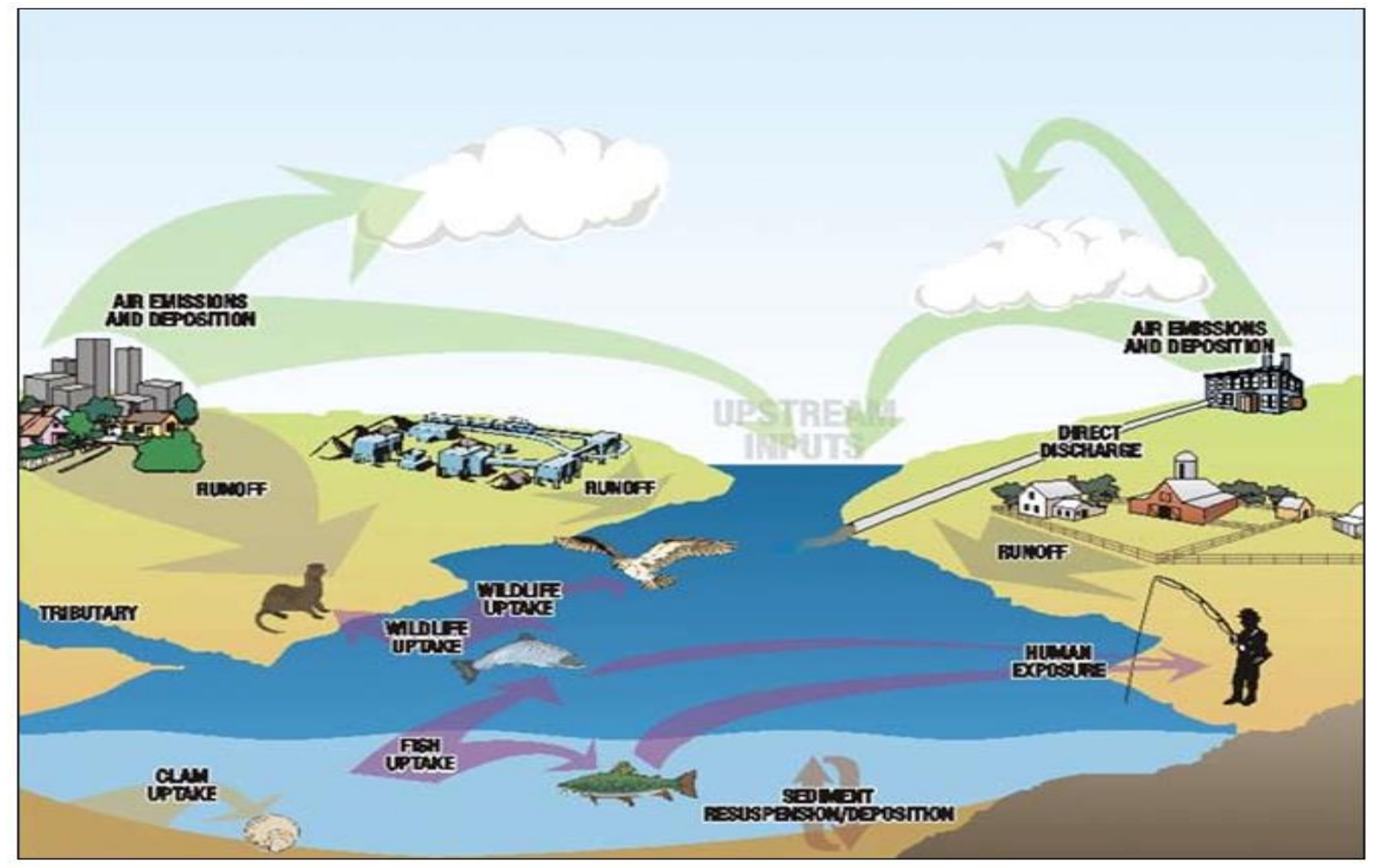

Figure 2 Toxic contaminant pathways in the environment (EPA, 2009)

\subsection{Contaminants of Concern in the Columbia River Basin}

There are primarily four contaminants of concern in the Columbia River Basin. These include mercury (including methylmercury), DDT and its breakdown products, PCBs, and PBDEs. There are four reasons that these pollutants have been identified as "contaminants of concern" in the Columbia River Basin. First, they widely exist throughout the basin. Second, they may have harmful effects on animals, fish, and people. Third, the toxins have been measured in most areas of the basin at a significant level. Fourth, it is possible to reduce the amount of these materials throughout the basin. For these reason, many environmental organization, government, and people are trying to improve the problems in the basin (EPA, 2009). 


\subsection{Polybrominated Diphenyl Ethers}

According to the United States Geological Survey (USGS) (2017), emerging contaminants are created unnaturally through chemical or biological processes in the environment and can cause abnormalities in the ecosystem and human health. EPA (2009) explains that PBDEs affect reproduction, development, and neurological system in people and animals, which can increase the risk of serious diseases such as cancer and hormone disorders. However, despite the toxic effects of PBDEs, they are widely used for building materials, electrical goods, automobiles, and hydroelectric dams. Due to the frequent use of the PBDEs, the pollutant has the potential to significantly contaminate the environment.

This paper mainly focuses on polybrominated diphenyl ethers (PBDEs) among contaminants of concern. PBDEs have been identified as emerging pollutants and much data has been collected (by the United States Geological Survey, for example) for PBDE concentrations throughout the Columbia River basin. According to the EPA (2014), PBDEs in the Upper Columbia River, increased rapidly from 1992 to 2000. This measured rise in PBDE levels has been identified as the steepest rise in the world (Rayne et al., 2003). One potential consequence of these pollutant's presence in the Columbia River basin has been identified in blood serum testing of residents in the state of Washington (Washington Toxics Coalition, 2006). While most PBDE levels measured in blood serum samples exist in the national median range, several samples exceeded the national range (see Figure 3). For example, one blood serum measured PBDEs at nearly two orders of magnitude greater than the national median range. The Columbia River is endangered from PBDEs. This thesis focuses on PBDEs, using a site-specific survey and simple overland flow assessment to qualify potential sources of the toxic material in the river. 


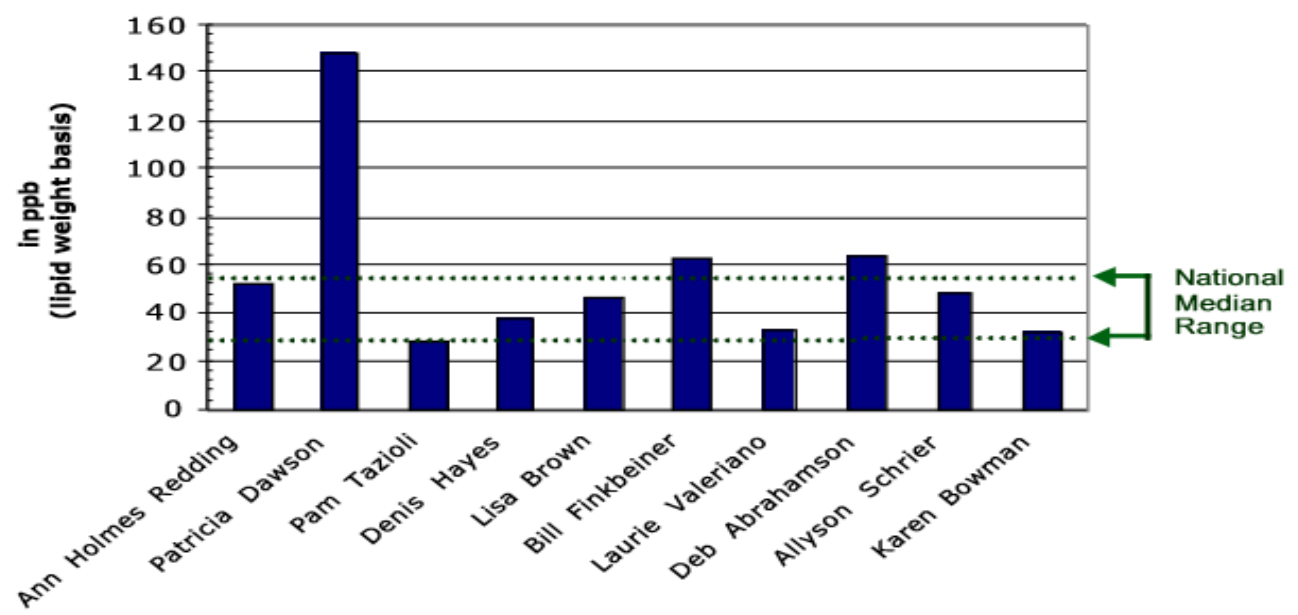

Figure 3 PBDE levels, measured in blood serum and expressed on a lipid weight basis.

(Washington Toxics Coalition, 2006)

\section{Survey}

\subsection{Indicator}

According to EPA (2009), indicator refers to specific organisms, sampling location, or contamination used for better understanding the public health and environment. There are various methods to investigate PBDEs from the Columbia River. For example, using instruments or chemicals can estimate the overall degree of contamination. However, in this thesis, the results from biological samples (for example, Columbia River Keepers and GSI Water Solutions, Inc.) are used to indicate level of contamination of PBDEs in the Columbia River as there is a close relationship between the species used as a biological sample and humans. Nilsen et al. (2014) stated that PBDEs are biomagnified through the Columbia River food chains. Indices of Longview and Columbia City have high contaminant concentration values, and the biggest part of the concentration is PBDEs (see Figure 4). According to Henny et al. (2011), PBDEs in osprey eggs rise consistently from rural Umatilla to downstream of Portland. 


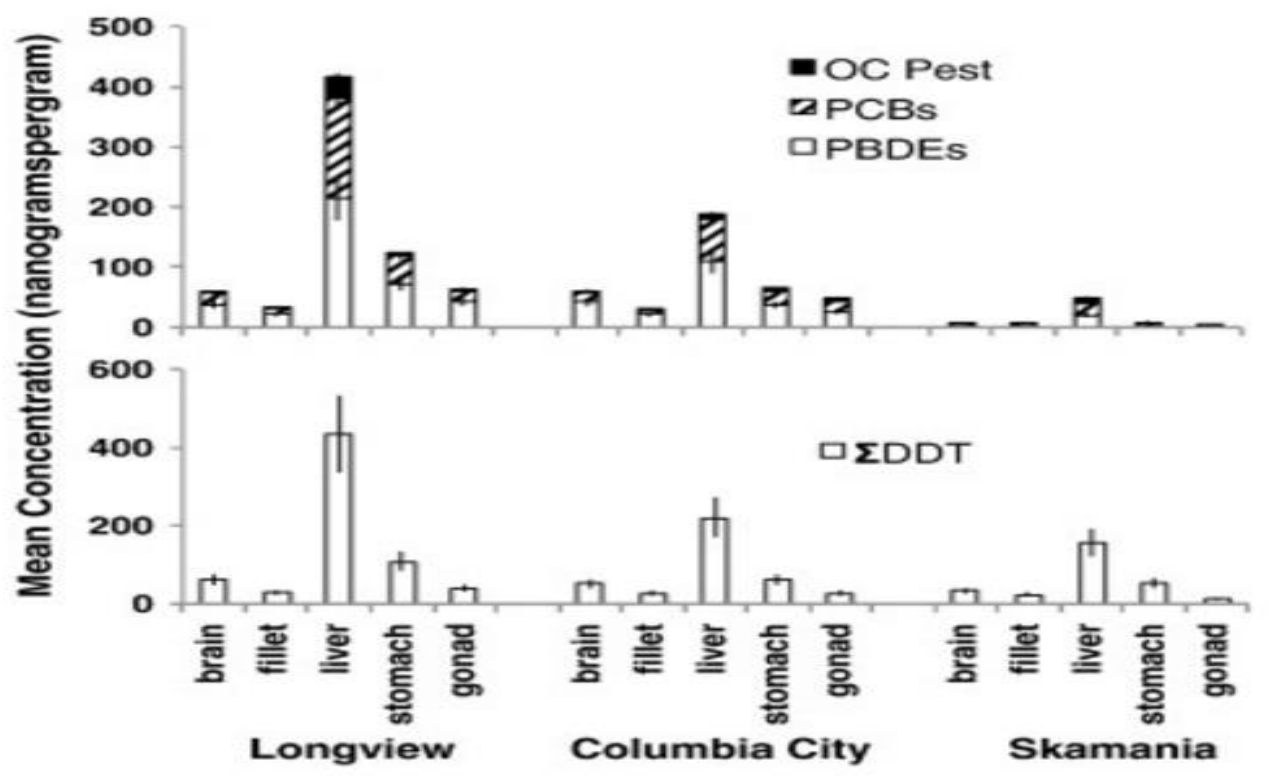

Figure 4 Contaminant concentrations (nanograms per gram, wet weight) in fish tissue composites for the three sites from 2009 collection. Error bars based on reported \%RSD values. (Nilsen et al., 2014)

\subsection{Biological Samples Used for the Survey}

The indicator species data used in this paper are from juvenile salmon, sturgeon, predatory birds, mink, otter, and Asian clam (EPA, 2009). These species were selected based on three advantages. First, the species as a biological sample are closely related to the Columbia River basin ecosystem because they are local species in the basin (EPA, 2009). Second, data gained from the samples can be used to represent the status of pollutants and trend pattern of contaminants because they are exposed with pollutants in long duration within a certain area. Finally, it is possible to make a comparison between the biological samples in the Columbia River basin ecosystem and the same species in other river basin ecosystems (EPA, 2009).

According to Johnson and Friese (2012), bioaccumulative toxic chemicals were continuously measured in all of the lower Columbia River resident fish. The toxins would eventually approach human race through food web. Therefore, to begin to address the long-term effects and necessary actions regarding the presence of PBDEs in the river, the Columbia River 
basin should be consistently monitored using indicator species (biological samples) (see Figure

5 , for example).

\section{Analysis of the Site of Interest}

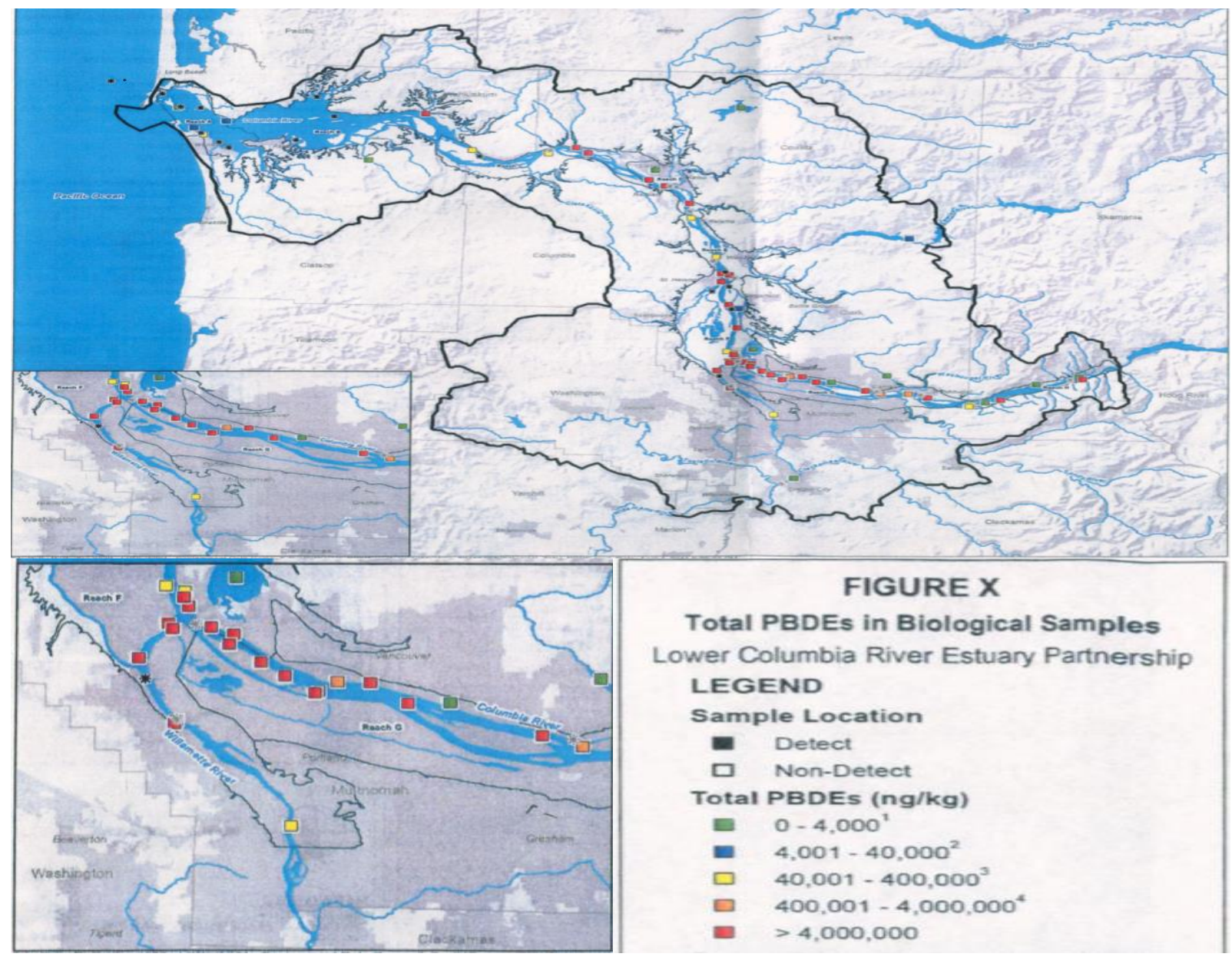

Figure 5 Total PBDEs in biological samples on the lower Columbia River (GSI Water Solution Inc., 2011)

\subsection{Site Selection for Water Quality Modeling}

PBDEs are detected along the Columbia River. According to the data map from GSI

Water Solution Inc. (2011), the high index of PBDEs contamination is concentrated at the confluence of the Columbia River and the Willamette River. This area has over 4,000,000 
(ng/kg) PBDEs in most survey locations. Due to this reason, this area primarily is analyzed to estimate potential source(s) of PBDEs. Specifically, the location of interest is river mile 101 (see Figure 6; Table 1). At river mile 101, Sauvie Island is on the left side of the basin, and there are farms and Vancouver Lake, WA on the right side of the basin.

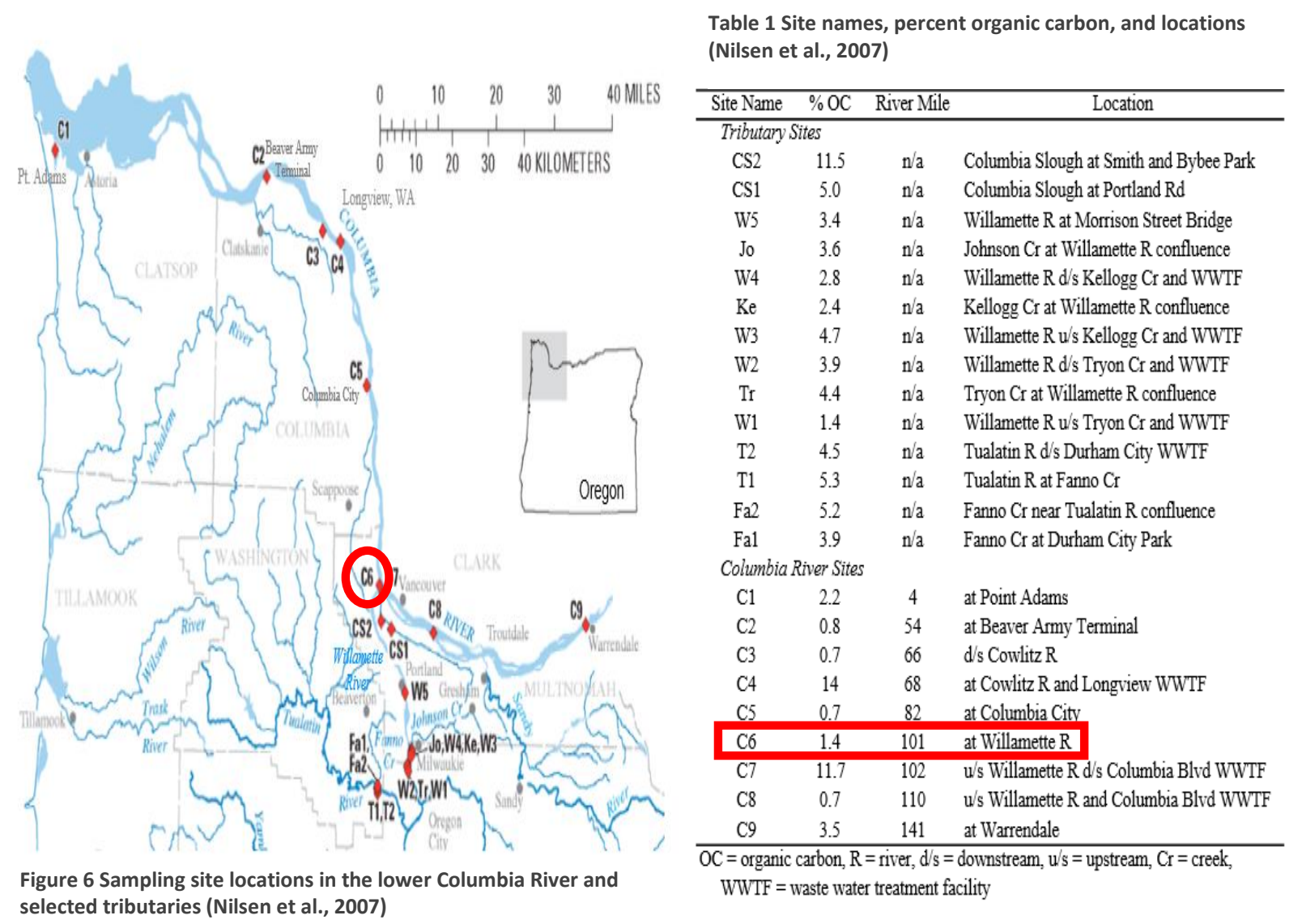

\subsection{Characteristics of the Location of Interest}

According to the ArcGIS data in this area, the location of the interest generally has a vast flatland surrounding the Columbia River, in which elevation is between approximately $8 \mathrm{ft}$ and 45ft. There is no high topography near the location, and the ground slope is gradual. According to West Multnomah Soil and Water Conservation District (2014), the slope of the land which is on the right side of the Columbia River Basin is very gentle and the location consists of soft soils 
such as silt clay loam (see Figure 7). According to Laenen et al. (1980), the Vancouver area,

which is on the right side of the Columbia River Basin, is constituted with a flatland. In addition,

Laenen et al. (1980) stated that the area contains alluvial soil deposited by the Columbia River.

Under the condition of the areas, infiltration would be expected to occur slowly and consistently.

Land use patterns within the location of interest is generally farming, entertainment, and harbor

logistics industry. Residential areas rarely exist near the basin (see Figure 9). Therefore, farming

and harbor logistics industry may be expected as potential source zones for PBDEs.

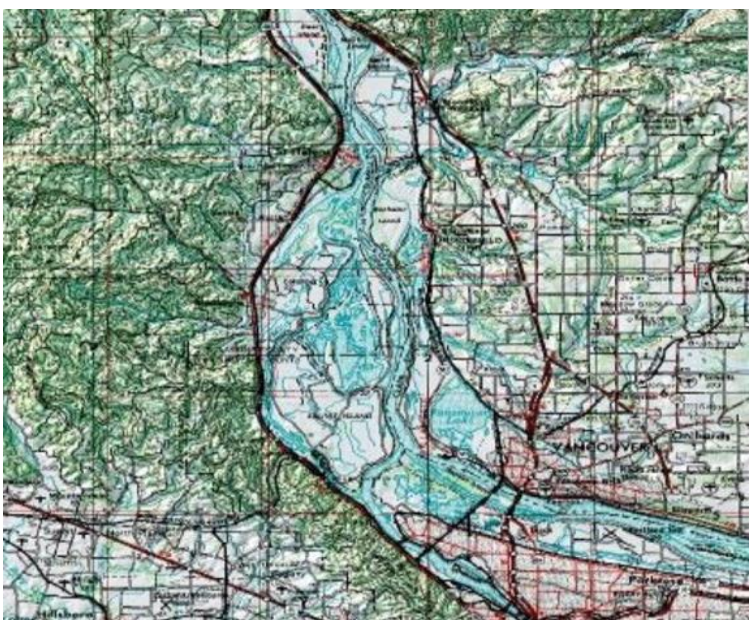

Figure 8 Topographic map of the location of interest from ArcGIS

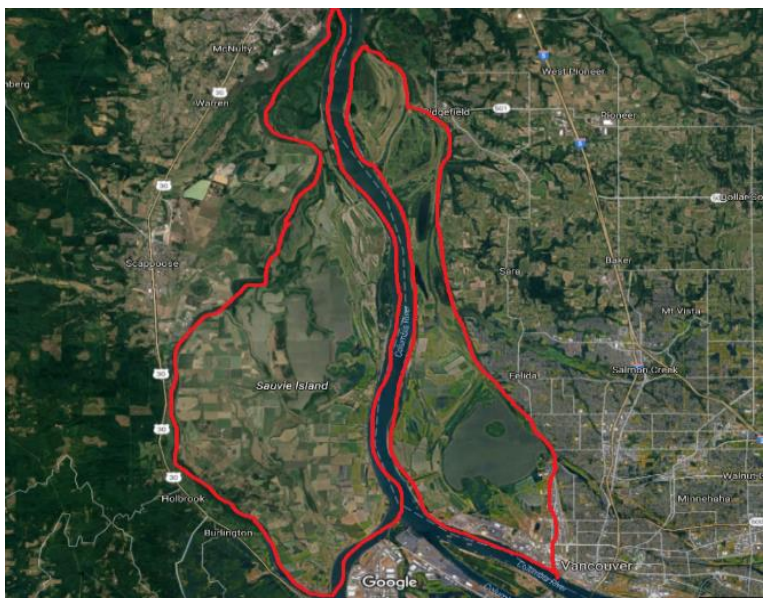

Figure 9 Aerial photograph of the location on interest from Google maps

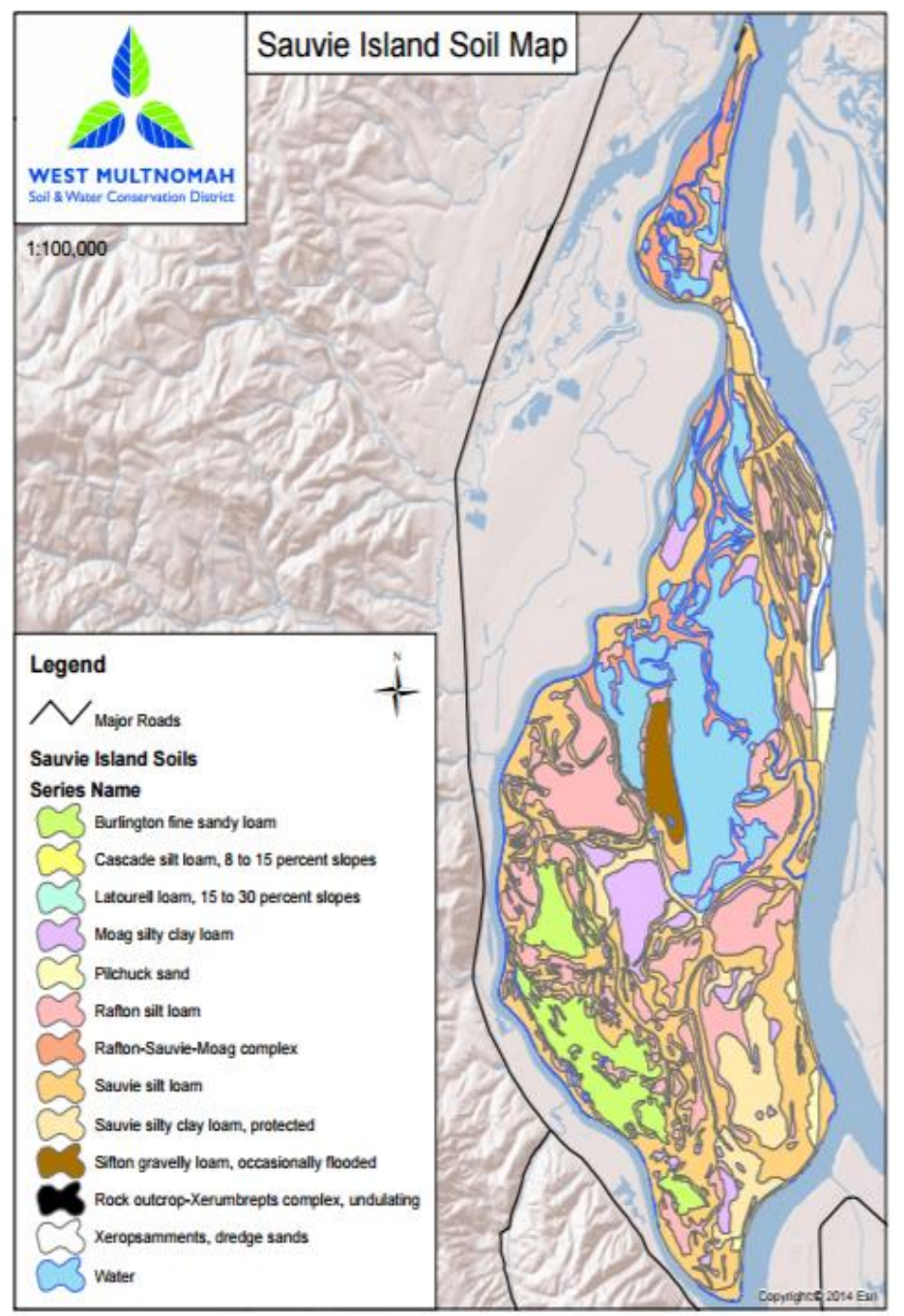

Figure 7 Sauvie Island soil map

(West Multnomah Soil and Water Conservation District, 2014) 
The specific details of the area of the river basin of interest have been surveyed from the region's topographic map (see Figure 10).

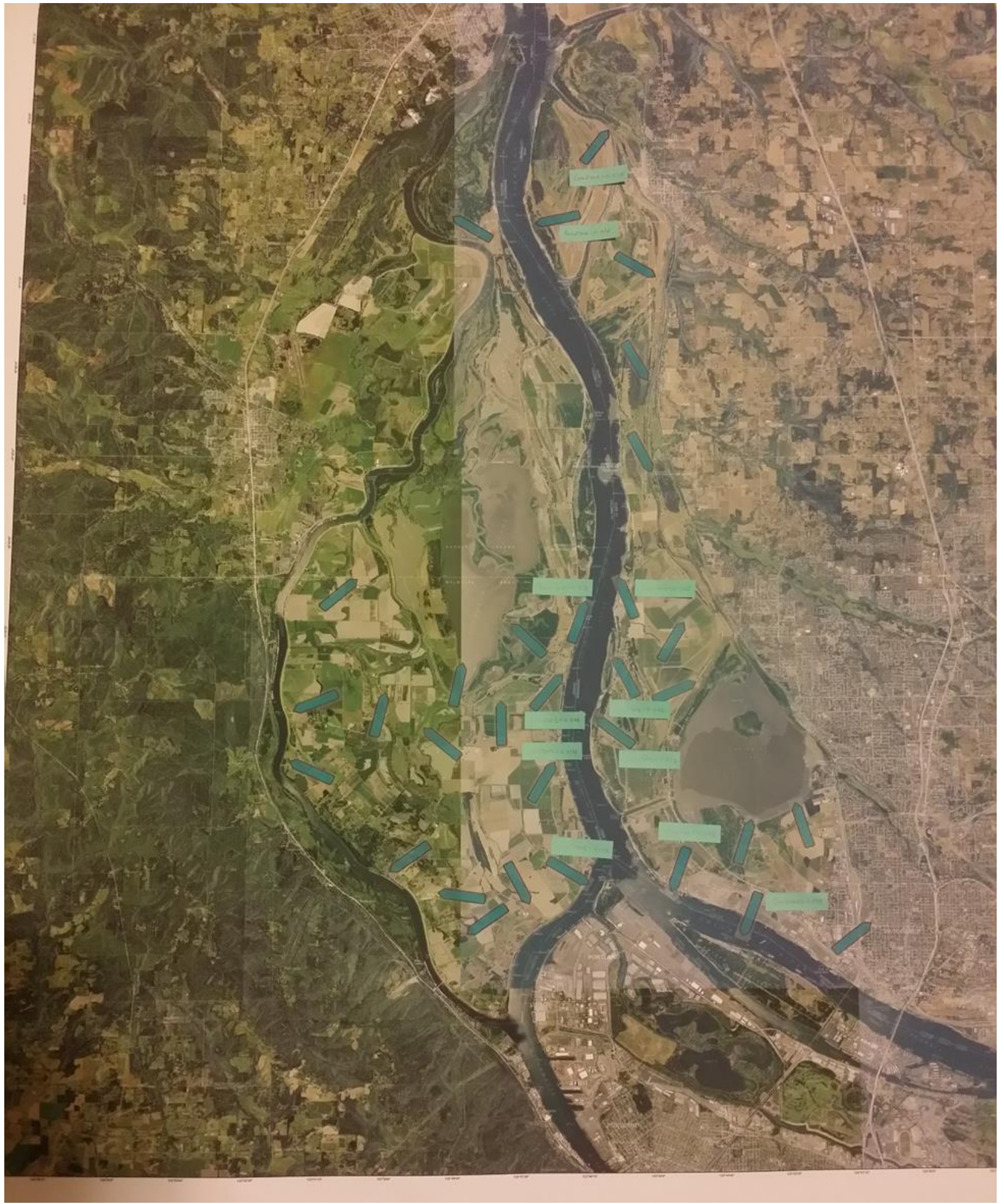

Figure 10 Topographic map for the directions of water flow and gradients 


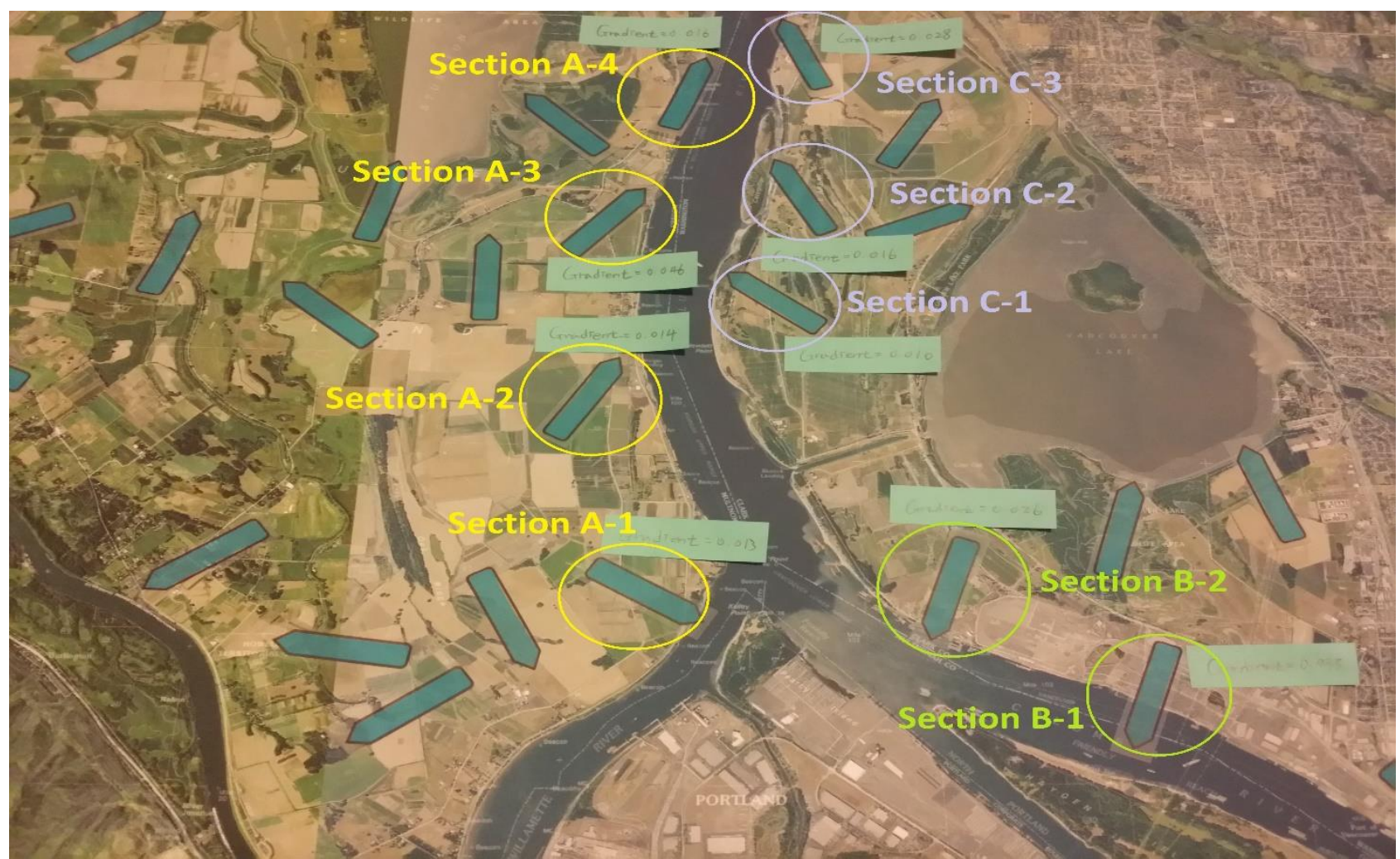

Figure 11 The directions of water flow and gradients of Section A, B, and C

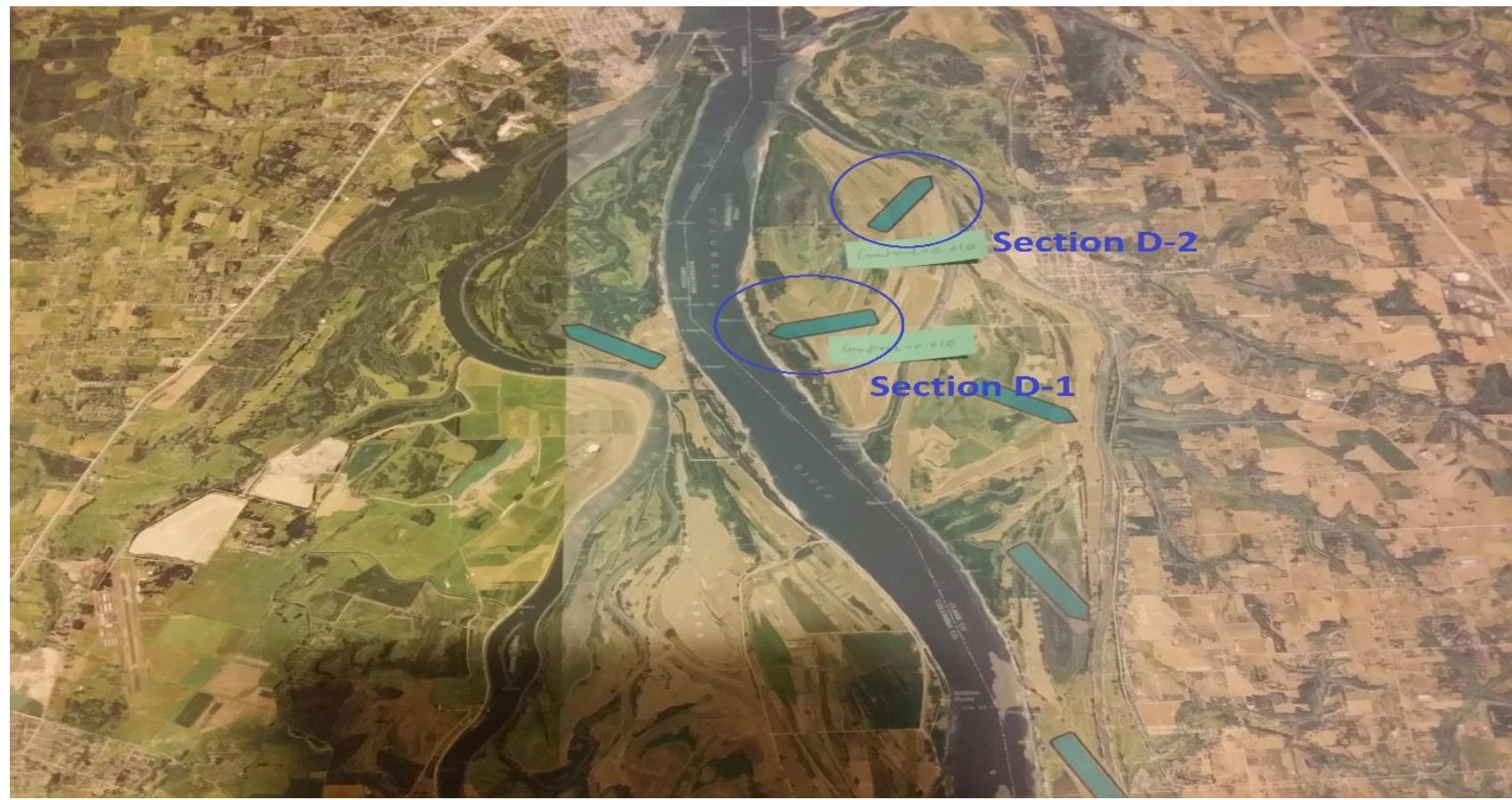

Figure 12 The direction of water flow and gradient of Section D 
In the map, the directions of water flow are estimated and marked according to contour lines. A survey of those flow paths/directions allows for assessment of the potential areas in the basin along river mile 101 that potentially affect water quality in the Columbia River (See Figure 10). For example, according to the survey shown in Figure 11, the west side of Sauvie Island does not have an impact on the Columbia River because overland flow in the section trends toward the Willamette River. A survey using this topographic map allowed for an estimate of the actual areas potentially affecting the water quality in the basin. These areas consist of four regions, identified as A, B, C, and D. Each area of the parts is $4.75 \mathrm{mi}^{2}, 2.3 \mathrm{mi}^{2}, 0.78 \mathrm{mi}^{2}$, and $2.99 \mathrm{mi}^{2}$, respectively.

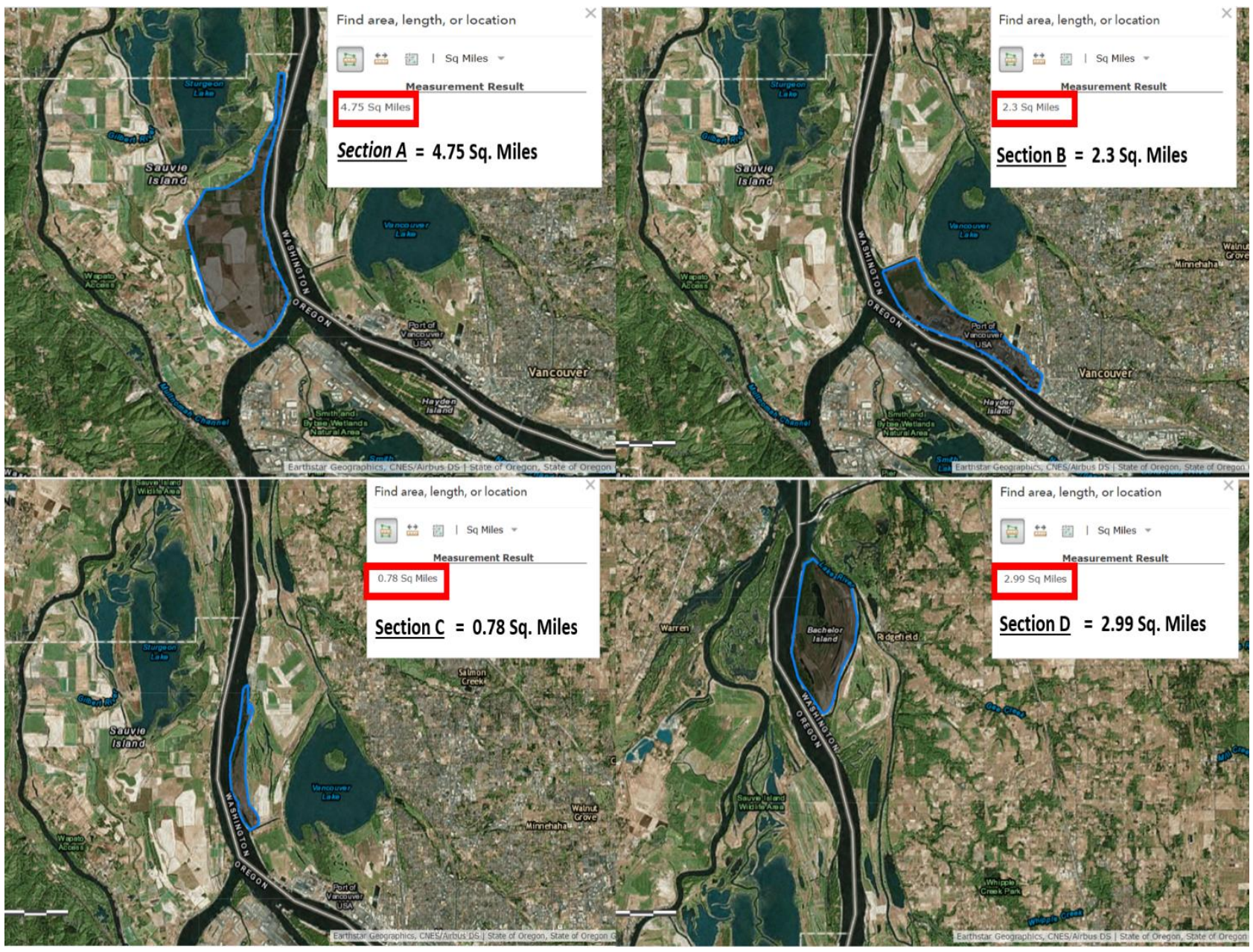

Figure 13 The estimated areas potentially affecting water quality of the Columbia River along river mile 101 (from ArcGIS maps) 


\section{Hydrologic Calculations for Water Quality Modeling}

The hydrologic calculations used in the research consist of three steps. First, the basin's intensity-duration-frequency (IDF) curve for a storm with a 2-year return period was determined from measured/available precipitation data. Second, the time of concentration for the various areas estimated from the topographic map survey was calculated. Finally, the magnitude of the 2year storm for the watershed was determined for each area (A, B, C, and D) of the basin. Those rainfall intensity values are used with the rational method to estimate peak discharge rates on the targeted areas. This assessment included several assumptions in the calculations. For example, this research does not consider influx of water, and associated pollutants, in the Columbia River upstream of the location of interest. This thesis will only focus on the influences potentially caused by land-usage patterns and overland flow of the surrounding river basin to the water quality of Columbia River.

\subsection{Intensity-Duration-Frequency (IDF) Curve of 2-year Return Period}

The magnitude of the 2-year storm on the watershed has been obtained from the intensity-duration-frequency (IDF) curve, and making the IDF curve is the most important factor in this section. To estimate the curve, historical precipitation data is needed. The precipitation data was collected from the USGS. The data was sorted for precipitation duration from largest to smallest intensities. The largest 25 precipitation data were chosen to calculate the magnitude of the 2-year storm. Each data was organized based on the time duration and intensity of precipitation (see Table 2). 
Table 2 Frequency analysis of different duration of precipitation depths

\begin{tabular}{|c|c|c|c|c|c|c|c|c|c|c|c|c|c|c|c|c|}
\hline & & & & & & & & $\begin{array}{r}\text { Intensity } \\
\quad \text { (in }\end{array}$ & $\mathrm{n} / \mathrm{min})$ & & & & & & & \\
\hline Rank & $1 \mathrm{hr}$ & $2 \mathrm{hr}$ & $3 \mathrm{hr}$ & $4 \mathrm{hr}$ & $5 \mathrm{hr}$ & $6 \mathrm{hr}$ & $7 \mathrm{hr}$ & $8 \mathrm{hr}$ & $9 \mathrm{hr}$ & $10 \mathrm{hr}$ & $11 \mathrm{hr}$ & $12 \mathrm{hr}$ & $13 \mathrm{hr}$ & $14 \mathrm{hr}$ & $15 \mathrm{hr}$ & $\begin{array}{c}\text { Return Period (yr), } \\
\mathrm{T}=((\mathrm{n}+1) / \mathrm{m})\end{array}$ \\
\hline 1 & 0.0035 & 0.0053 & 0.0071 & 0.0061 & 0.0055 & 0.0049 & 0.0044 & 0.0035 & 0.0032 & 0.0031 & 0.0031 & 0.0032 & 0.0030 & 0.0028 & 0.0027 & 35.00 \\
\hline 2 & 0.0033 & 0.0043 & 0.0041 & 0.0038 & 0.0039 & 0.0039 & 0.0038 & 0.0032 & 0.0030 & 0.0029 & 0.0031 & 0.0030 & 0.0028 & 0.0028 & 0.0026 & 17.50 \\
\hline 3 & 0.0030 & 0.0029 & 0.0026 & 0.0024 & 0.0024 & 0.0029 & 0.0031 & 0.0029 & 0.0028 & 0.0028 & 0.0026 & 0.0028 & 0.0028 & 0.0027 & 0.0026 & 11.67 \\
\hline 4 & 0.0023 & \begin{tabular}{|l|l|} 
\\
\end{tabular} & 0.0025 & 0.0021 & 0.0024 & 0.0028 & 0.0029 & 0.0025 & 0.0026 & 0.0027 & 0.0026 & 0.0023 & 0.0023 & 0.0023 & 0.0023 & 8.75 \\
\hline 5 & 0.0023 & 0.0024 & 0.0024 & 0.0021 & 0.0024 & 0.0024 & 0.0024 & 0.0023 & 0.0023 & 0.0021 & 0.0022 & 0.0020 & 0.0021 & 0.0023 & 0.0022 & 7.00 \\
\hline 6 & 0.0018 & 0.0019 & 0.0022 & 0.0021 & 0.0023 & 0.0023 & 0.0024 & 0.0023 & 0.0023 & 0.0021 & 0.0019 & 0.0019 & 0.0020 & 0.0019 & 0.0019 & 5.83 \\
\hline 7 & 0.0018 & 0.0018 & 0.0019 & 0.0020 & 0.0022 & 0.0023 & 0.0023 & 0.0023 & 0.0021 & 0.0021 & 0.0019 & 0.0018 & 0.0018 & 0.0019 & 0.0018 & 5.00 \\
\hline 8 & 0.0017 & 0.0018 & 0.0018 & 0.0020 & 0.0022 & 0.0023 & 0.0022 & 0.0022 & 0.0020 & 0.0020 & 0.0018 & 0.0018 & 0.0018 & 0.0018 & \begin{tabular}{|l|l|}
0.0017 \\
\end{tabular} & 4.38 \\
\hline 9 & 0.0013 & \begin{tabular}{|l}
0.0017 \\
\end{tabular} & 0.0017 & 0.0020 & 0.0021 & 0.0022 & 0.0022 & 0.0021 & 0.0020 & 0.0019 & 0.0017 & 0.0018 & 0.0017 & 0.0017 & 0.0017 & 3.89 \\
\hline 10 & 0.0013 & 0.0016 & 0.0017 & 0.0019 & 0.0020 & 0.0021 & 0.0021 & 0.0021 & 0.0020 & 0.0019 & 0.0017 & 0.0016 & 0.0017 & 0.0016 & 0.0015 & 3.50 \\
\hline 11 & 0.0013 & \begin{tabular}{|l|l|} 
\\
\end{tabular} & 0.0014 & 0.0018 & 0.0019 & 0.0021 & 0.0020 & 0.0019 & 0.0020 & 0.0018 & 0.0017 & 0.0016 & 0.0016 & 0.0016 & 0.0015 & 3.18 \\
\hline 12 & 0.0012 & \begin{tabular}{|l|l|}
0.0014 \\
\end{tabular} & 0.0014 & 0.0017 & 0.0019 & 0.0021 & 0.0019 & 0.0019 & 0.0019 & 0.0018 & \begin{tabular}{|l|l|}
0.0017 \\
\end{tabular} & 0.0016 & 0.0016 & 0.0015 & 0.0015 & 2.92 \\
\hline 13 & 0.0010 & \begin{tabular}{|l|l|} 
\\
\end{tabular} & 0.0013 & 0.0016 & 0.0019 & 0.0019 & 0.0019 & 0.0018 & 0.0019 & 0.0018 & 0.0016 & 0.0016 & 0.0015 & 0.0015 & 0.0015 & 2.69 \\
\hline 14 & 0.0010 & 0.0013 & 0.0013 & 0.0015 & 0.0017 & 0.0019 & 0.0018 & 0.0018 & 0.0018 & 0.0018 & 0.0016 & 0.0015 & 0.0015 & 0.0015 & 0.0014 & 2.50 \\
\hline 15 & 0.0008 & 0.0011 & 0.0013 & & 0.0015 & 0.0016 & 0.0017 & 0.0017 & 0.0016 & 0.0017 & 0.0015 & 0.0015 & 0.0015 & 0.0014 & 0.0014 & 2.33 \\
\hline 16 & 0.0008 & 0.0011 & 0.0013 & 0.0015 & 0.0014 & 0.0015 & 0.0015 & 0.0017 & 0.0015 & 0.0017 & 0.0014 & 0.0014 & 0.0013 & 0.0014 & 0.0014 & 2.19 \\
\hline 17 & 0.0007 & 0.0011 & 0.0012 & 0.0014 & 0.0014 & 0.0014 & 0.0015 & 0.0016 & 0.0015 & 0.0016 & 0.0013 & 0.0012 & 0.0012 & 0.0013 & 0.0012 & 2.06 \\
\hline 18 & 0.0007 & 0.0008 & 0.0012 & 0.0014 & 0.0014 & 0.0014 & 0.0014 & 0.0013 & 0.0015 & 0.0016 & 0.0013 & 0.0011 & 0.0012 & 0.0012 & 0.0012 & 1.94 \\
\hline 19 & 0.0005 & 0.0008 & 0.0012 & 0.0012 & 0.0013 & 0.0013 & 0.0014 & 0.0013 & 0.0013 & 0.0015 & 0.0010 & 0.0009 & 0.0010 & 0.0010 & 0.0000 & 1.84 \\
\hline 20 & 0.0005 & 0.0008 & 0.0010 & 0.0011 & 0.0012 & 0.0013 & 0.0013 & 0.0013 & 0.0012 & 0.0014 & 0.0009 & 0.0000 & 0.0000 & 0.0000 & 0.0000 & 1.75 \\
\hline 21 & 0.0005 & 0.0008 & 0.0010 & 0.0011 & 0.0012 & 0.0013 & 0.0013 & 0.0012 & 0.0012 & 0.0013 & 0.0000 & 0.0000 & 0.0000 & 0.0000 & 0.0000 & 1.67 \\
\hline 22 & 0.0003 & 0.0007 & 0.0008 & 0.0010 & 0.0011 & 0.0012 & 0.0012 & 0.0011 & 0.0012 & 0.0012 & 0.0000 & 0.0000 & 0.0000 & 0.0000 & 0.0000 & 1.59 \\
\hline 23 & 0.0003 & 0.0007 & 0.0008 & 0.0010 & 0.0011 & 0.0011 & 0.0012 & 0.0011 & 0.0009 & 0.0010 & 0.0000 & 0.0000 & 0.0000 & 0.0000 & 0.0000 & 1.52 \\
\hline 24 & 0.0003 & 0.0006 & 0.0008 & 0.0009 & 0.0010 & 0.0011 & 0.0010 & 0.0008 & 0.0005 & 0.0007 & 0.0000 & 0.0000 & 0.0000 & 0.0000 & 0.0000 & 1.46 \\
\hline 25 & 0.0003 & 0.0005 & 0.0008 & 0.0009 & 0.0010 & 0.0011 & 0.0009 & 0.0008 & 0.0004 & 0.0000 & 0.0000 & 0.0000 & 0.0000 & 0.0000 & 0.0000 & 1.40 \\
\hline 26 & 0.0003 & 0.0005 & 0.0006 & 0.0009 & 0.0009 & 0.0009 & 0.0009 & 0.0005 & 0.0000 & 0.0000 & 0.0000 & 0.0000 & 0.0000 & 0.0000 & 0.0000 & 1.35 \\
\hline 27 & 0.0003 & 0.0005 & 0.0006 & 0.0008 & 0.0008 & 0.0008 & 0.0006 & 0.0004 & 0.0000 & 0.0000 & 0.0000 & 0.0000 & 0.0000 & 0.0000 & 0.0000 & 1.30 \\
\hline 28 & 0.0002 & 0.0005 & 0.0006 & 0.0007 & 0.0006 & 0.0007 & 0.0006 & 0.0000 & 0.0000 & 0.0000 & 0.0000 & 0.0000 & 0.0000 & 0.0000 & 0.0000 & 1.25 \\
\hline 29 & 0.0002 & 0.0004 & 0.0005 & 0.0006 & 0.0005 & 0.0006 & 0.0005 & 0.0000 & 0.0000 & 0.0000 & 0.0000 & 0.0000 & 0.0000 & 0.0000 & 0.0000 & 1.21 \\
\hline 30 & 0.0002 & 0.0003 & 0.0004 & 0.0005 & 0.0005 & 0.0004 & 0.0004 & 0.0000 & 0.0000 & 0.0000 & 0.0000 & 0.0000 & 0.0000 & 0.0000 & 0.0000 & 1.17 \\
\hline 31 & 0.0002 & 0.0003 & 0.0004 & 0.0004 & 0.0004 & 0.0004 & 0.0000 & 0.0000 & 0.0000 & 0.0000 & 0.0000 & 0.0000 & 0.0000 & 0.0000 & 0.0000 & 1.13 \\
\hline 32 & 0.0002 & 0.0003 & 0.0004 & & 0.0004 & 0.0004 & 0.0000 & 0.0000 & 0.0000 & 0.0000 & 0.0000 & 0.0000 & 0.0000 & 0.0000 & 0.0000 & 1.09 \\
\hline 33 & 0.0002 & \begin{tabular}{|l|l|} 
\\
\end{tabular} & 0.0002 & 0.0004 & 0.0003 & 0.0000 & 0.0000 & 0.0000 & 0.0000 & 0.0000 & 0.0000 & 0.0000 & 0.0000 & 0.0000 & 0.0000 & 1.06 \\
\hline 34 & 0.0002 & 0.0002 & 0.0002 & 0.0003 & 0.0000 & 0.0000 & 0.0000 & 0.0000 & 0.0000 & 0.0000 & 0.0000 & 0.0000 & 0.0000 & 0.0000 & 0.0000 & 1.03 \\
\hline
\end{tabular}


Table 3 provides the intensities of duration at 2.06-year and 1.94-year return period. To identify the intensity of duration at the 2-year return period, the two data were interpolated. After the interpolation, the result of the calculation is shown below the table (see Table 3 ). The resulting IDF curve is shown in Figure 14.

Table 3 Intensity of duration at 2-year return period

\begin{tabular}{|c|c|c|c|c|c|c|c|c|c|c|c|c|c|c|c|c|}
\hline \multicolumn{17}{|c|}{ Intensity of Duraion (in/hr) } \\
\hline Return period (yr) & $1 \mathrm{hr}$ & & $2 \mathrm{hr}$ & $3 \mathrm{hr}$ & $4 \mathrm{hr}$ & $5 \mathrm{hr}$ & $6 \mathrm{hr}$ & $7 \mathrm{hr}$ & $8 \mathrm{hr}$ & $9 \mathrm{hr}$ & $10 \mathrm{hr}$ & $11 \mathrm{hr}$ & $12 \mathrm{hr}$ & $13 \mathrm{hr}$ & $14 \mathrm{hr}$ & $15 \mathrm{hr}$ \\
\hline 2.0 & & 0.01 & 0.008125 & 0.006111 & 0.005313 & 0.0043 & 0.003542 & 0.003108 & 0.002938 & 0.002536 & 0.00245 & 0.001772 & 0.001528 & 0.001415 & 0.001439 & 0.001244 \\
\hline 1.9 & & 0.01 & 0.00625 & 0.006111 & 0.005313 & 0.0042 & 0.003403 & 0.003057 & 0.002507 & 0.002505 & 0.002325 & 0.001752 & 0.001389 & 0.001327 & 0.001236 & 0.001178 \\
\hline \multicolumn{17}{|c|}{ Intensity of Duraion (in/hr) } \\
\hline Return period (yr) & $1 \mathrm{hr}$ & & $2 \mathrm{hr}$ & $3 \mathrm{hr}$ & $4 \mathrm{hr}$ & $5 \mathrm{hr}$ & $6 \mathrm{hr}$ & $7 \mathrm{hr}$ & $8 \mathrm{hr}$ & $9 \mathrm{hr}$ & $10 \mathrm{hr}$ & $11 \mathrm{hr}$ & $12 \mathrm{hr}$ & $13 \mathrm{hr}$ & $14 \mathrm{hr}$ & $15 \mathrm{hr}$ \\
\hline & 2 & 0.01 & 0.007187 & 0.006111 & 0.005313 & 0.00425 & 0.003472 & 0.003083 & 0.002722 & 0.00252 & 0.002388 & 0.001762 & 0.001458 & 0.001371 & 0.001338 & 0.001211 \\
\hline
\end{tabular}

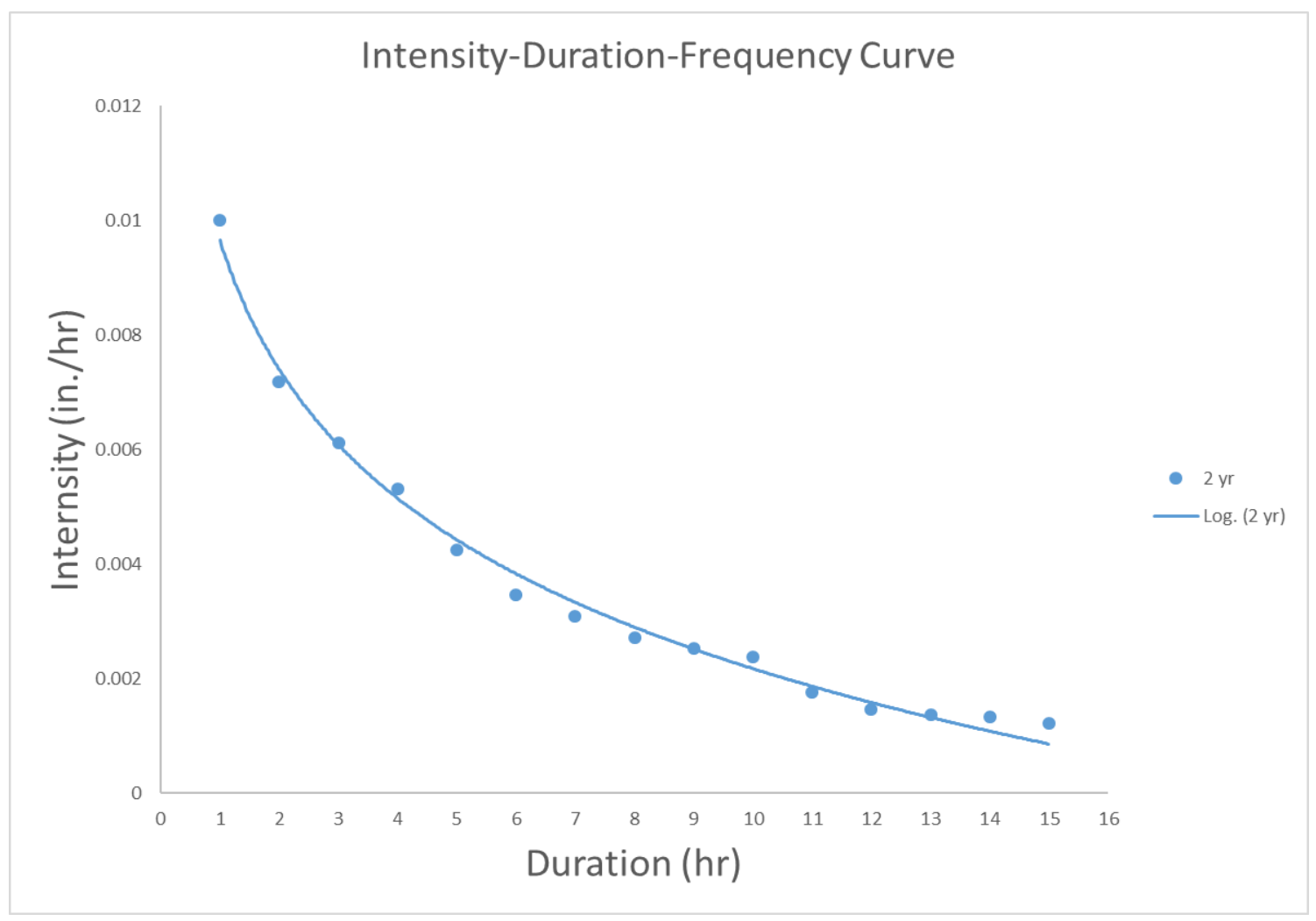

Figure 14 Intensity-duration-frequency curve at 2-year return period 


\subsection{Time of Concentration and Magnitude of the 2-year Storm}

Gupta (2008) defines time of concentration as the travel time of water from the hydraulically most distant point on a watershed to the location of interest, creating outflux on the basin. There are various empirical equations for time of concentration. In this research, the Kirpich method, defined below as Equation 1, was used to estimate the time of concentration on the watershed.

$$
t_{C}=0.0078 * \frac{L^{0.77}}{S^{0.385}}
$$

where $t_{c}$ is the time of concentration, $L$ refers to the distance between the hydraulic most distant point and outflux of the basin, and $S$ is defined as the slope of the flow path. As discussed previously, estimates of ground slope, $S$, and the length of flow, $L$, were done using the watershed's topographic map (see above Figure 11; Figure 12). While putting the values into Kirpich method, time of concentration (min) is calculated. After the calculation of the time of concentration, the magnitude of the 2-year storm can be determined with the IDF curve (as reported in Table 4). Finally, for the peak discharge rates in actual areas, the rational method is used (see Equation 2).

$$
Q=C_{f} C I A
$$

where $C_{f}$ refers to the frequency factor, assumed to equal 1 for this 2 -year storm, $C$ is rational runoff coefficient and is simply determined depending on land use pattern, $I$ indicates rainfall intensity, and $A$ expresses the areas of contributing to overland flow on the watershed. In this research, the highest intensity in each section is used to calculate peak discharge rate for each section. All of the results are calculated and shown in Table 4. 
Table 4 Peak Discharge Rate Estimates

\begin{tabular}{|c|c|c|c|c|c|c|c|c|c|}
\hline Section & Section & $L(\mathrm{ft})$ & $S$ & $\begin{array}{c}\text { tc } \\
\text { (min) }\end{array}$ & I (in/hr.) & Area (ft2) & $\mathrm{Cf}$ & C & $\begin{array}{c}\mathrm{Q} \\
(\mathrm{ft} 3 / \mathrm{sec})\end{array}$ \\
\hline \multirow{4}{*}{ A } & A-1 & 9074.3 & 0.013 & 46.84 & 0.0104 & \multirow{4}{*}{132420000} & \multirow{4}{*}{1} & \multirow{4}{*}{0.3} & \multirow{4}{*}{620.9} \\
\hline & A-2 & 9422.1 & 0.014 & 46.68 & 0.0105 & & & & \\
\hline & $A-3$ & 12194 & 0.046 & 35.75 & 0.0113 & & & & \\
\hline & $A-4$ & 8201.8 & 0.016 & 39.77 & 0.0109 & & & & \\
\hline \multirow{2}{*}{ B } & B-1 & 2580 & 0.035 & 12.01 & 0.0145 & \multirow{2}{*}{64120000} & \multirow{2}{*}{1} & \multirow{2}{*}{0.9} & \multirow{2}{*}{1164.3} \\
\hline & B-2 & 2713.3 & 0.026 & 14.09 & 0.0140 & & & & \\
\hline \multirow{3}{*}{ C } & C-1 & 5106.7 & 0.010 & 32.40 & 0.0115 & \multirow{3}{*}{21745000} & \multirow{3}{*}{1} & \multirow{3}{*}{0.3} & \multirow{3}{*}{114.2} \\
\hline & $\mathrm{C}-2$ & 6360.6 & 0.016 & 32.21 & 0.0116 & & & & \\
\hline & $C-3$ & 5332.1 & 0.028 & 22.76 & 0.0126 & & & & \\
\hline \multirow{2}{*}{ D } & D-1 & 5087.3 & 0.010 & 32.30 & 0.0116 & \multirow{2}{*}{83356000} & \multirow{2}{*}{1} & \multirow{2}{*}{0.3} & \multirow{2}{*}{401.4} \\
\hline & $D-2$ & 11228 & 0.010 & 59.43 & 0.0097 & & & & \\
\hline
\end{tabular}

$*$ L= Length of Flow Path, $\mathrm{ft}$

* I= Rainfall Intensity, in/hr.

* $\mathrm{S}=$ Slope of Flow Path, $\mathrm{ft} / \mathrm{ft}$

$* \mathrm{tc}=$ Time of Concentration, min

* $\mathrm{Q}=$ Discharge Rate $(\mathrm{ft} 3 / \mathrm{sec})$

* $\mathrm{Cf}=$ Frequency Factor, 2 to 10 -year return period

* C= Rational Runoff Coefficient

\section{Water quality modeling}

\subsection{Analysis of the Data}

As shown in Table 4, the area of section A is $132,420,000 \mathrm{ft}^{2}$, and the greatest rainfall intensity of a 2-year storm on this portion of the watershed is approximately $0.0113 \mathrm{in} / \mathrm{hr}$, which is the highest intensity among the subsections of A and is used for the peak discharge rate in section A. The calculated peak discharge rate of section A is $620.9 \mathrm{cfs}$. Section A has the second highest peak discharge rate among the targeted areas. This suggests that this area is expected to significantly affect the water quality of the Columbia River, especially along river mile 101. Most of areas of section A are used for agriculture (see above Figure 11). Section B consists of $64,120,000 \mathrm{ft}^{2}$, and the greatest rainfall intensity of the area is $0.0145 \mathrm{in} / \mathrm{hr}$, which is the highest 
value among intensities of the subsections of $B$ and is utilized to determine the peak discharge

rate in section B. The peak discharge rate of section B is $1164.3 \mathrm{cfs}$. The overall land use pattern of section $\mathrm{B}$ is harbor logistics industry (see above Figure 11). The extent of section $\mathrm{C}$ is $21,745,000 \mathrm{ft}^{2}$. The intensity of section $\mathrm{C}$ is $0.0126 \mathrm{in} / \mathrm{hr}$, which is the highest value in the subsections of $\mathrm{C}$ and is applied for the peak discharge rate of the section $\mathrm{C}$. The value in the section $\mathrm{C}$ is $114.2 \mathrm{cfs}$, which is the smallest discharge rate among the rates, and this area is utilized for agriculture (see Figure 15). Section D has $83,356,000 \mathrm{ft}^{2}$ and $0.0116 \mathrm{in} / \mathrm{hr}$ of the intensity, which is the highest value in the section $\mathrm{D}$ and is used for the peak discharge rate. The peak discharge rate of section D is $401.4 \mathrm{cfs}$, which is the third highest value. Section D is made up of farming areas (see above Figure 12). Therefore, the estimated peak discharge rate associated with overland flow in these areas of the Columbia River basin is approximately 2300.8 cfs.

\subsection{Simple Assessment of Overland Flow and Potential Impacts}

A simple model combined with a survey of the site and hydrologic characteristics was used to estimate overland flow in the Columbia River basin along river mile 101. Results of the survey suggest areas of the river basin potentially affecting the water quality of the Columbia River (as discussed in Chapter 3). The survey results also suggest possible nonpoint source zones for PBDEs from these delineated areas of the basin. From the areas, PBDEs can be carried along with overland water flow into the river. In this paper, the relationship between the degree of PBDEs contamination and the peak discharge rate is simply assumed as they are proportional. It is assumed that depending on the peak discharge rate of the area, the degree of influx of PBDEs 
can be expected to be directly related. Additionally, the peak discharge rate can simply increase the possibility of the influx of PBDEs from these possible nonpoint source areas.

According to the estimates of peak discharge rates in the basin, section B may most strongly affect the water quality and contamination of the river. Section B is utilized for harbor logistics industry area, and the main potential matters polluting the river with PBDEs can be expected as plastic, building materials, and various residuals created by transportation. The majority of the area of sections A, C, and D are used for agriculture, with very little residential and no industrial areas. The main potential materials causing the influx of PBDEs in these sections are assumed to be associated with agricultural pesticides and chemical fertilizers. The peak discharge rate of the section A is the second highest (see Table 4), and this area may account for a significant portion of the contamination of PBDEs in the Columbia River along river mile 101. In addition, Sections D and C may play a significant role in the level of PBDEs in the Columbia River. This is because according to Figure 5, the Columbia River Mile 101 has the highest value of PBDEs among the measurements of PBDEs and the level of the contamination is over 4,000,000 (ng/kg). Finally, the potential PBDEs contamination routes, sources, and degrees are expected through a simple model of overland flow.

\section{Conclusion}

The Columbia River has been closely connected with surrounding areas because many people near the basin, as well as the ecosystem depend on water, energy, food, and habitants from the river. As such, the Columbia River has played an important role in meeting the demands of the ecosystem, and it should be protected from serious contamination. The potential impact of the contamination can be significantly proliferated through the basin. This research is 
concentrated on the pollution of PBDEs in the river. PBDEs were chosen because it is one of primary contaminants of concern in the river and the toxin has widely been utilized in industrial areas and farming areas near the basin. The greatest concentrations of PBDEs measured in biological samples collected along the Columbia River Basin is located at the Columbia River mile 101 with reported levels greater than 4,000,000 ng/kg. Through the analysis of the simple model of overland flow, the possible nonpoint sources and potential impacts on PBDE concentrations in the Columbia River along river mile 101 were determined. Consequently, agricultural pesticides and fertilizers and pollutants created from industrial field are inferred as cause of the highest degree of PBDEs contamination in this area. To control the contamination, consistent monitoring in terms of PBDEs in the Columbia River, regulations to reduce use of artificial or chemical materials causing PBDEs pollution, attention to the issue, and lively discussions about the problem are expected and needed. 


\section{Reference:}

Columbia Basin Research in School of Aquatic and Fishery Sciences, University of Washington (2017). Columbia and Snake Rivers Hydroelectric Project Information Retrieved from http://www.cbr.washington.edu/hydro.

GSI Water Solution Inc. (2011). Contaminant Rate Comparison and Synthesis: LCREP. Personal Communication, 2011.

Gupta, R. (2008). Hydrology and Hydraulic Systems (3rd ed.). Long Grove, Ill.: Waveland Press.

Henny, C., Grove, J., Kaiser, R., Johnson, A., Furl, J., and Letcher, L. (2011). Wastewater dilution index partially explains observed polybrominated diphenyl ether flame retardant concentrations in osprey eggs from Columbia River Basin, 2008-2009. Ecotoxicology, 20(4), 682-697.

Independent Scientific Advisory Board (2007). Human population impacts on Columbia River basin fish and wildlife. (Document (Independent Scientific Advisory Board); 2007-3). Portland, Or.]: Independent Scientific Advisory Board

Johnson, A. and Friese, M. (2012) PBTs analyzed in bottom fish from four Washington rivers and lakes: hexabromocyclododecane, tetrabromobisphenol a, chlorinated paraffins, polybrominated diphenylethers, polychlorinated naphthalenes, perfluorinated organic compounds, lead, and cadmium. Retrieved March 22, 2017, from https://fortress.wa.gov/ecy/publications/summarypages/1203042.html.

Laenen, A., Geological Survey, Portland (1980). Storm runoff as related to urbanization in the Portland, Oregon-Vancouver, Washington area (Water-resources investigations). Portland, OR: U.S. Geological Survey.

Loge, F., Arkoosh, M., Ginn, T., Johnson, L., and Collier, T. (2005). Impact of environmental stressors on the dynamics of disease transmission. Environmental Science \& Technology, 39(18), 7329-36.

Nilsen, E. B., Rosenbauer, R. R., Furlong, E. T., Burkhardt, M. R., Werner, S. L., Greaser, L., and Noriega, M. (2007). Pharmaceuticals, personal care products and anthropogenic waste indicators detected in streambed sediments of the lower Columbia River and selected tributaries. National Ground Water Association, Paper, 4483, 15.

Nilsen, E., Zaugg, S., Alvarez, D., Morace, J., Waite, I., Counihan, T.,Hardiman, J., Torres, L., Patiño, R., Mesa, M., and Grove, R. (2014). Contaminants of legacy and emerging concern in largescale suckers (Catostomus macrocheilus) and the foodweb in the lower Columbia River, Oregon and Washington, USA. Science of the Total Environment, 484, 344-352. 
Rayne, S., Ikonomou, M., and Antcliffe, B. (2003). Rapidly increasing polybrominated diphenyl ether concentrations in the Columbia River system from 1992 to 2000. Environmental Science \& Technology, 37(13), 2847-54.

United States Environmental Protection Agency (EPA) Region X (2009). Columbia River basin: State of the river report for toxics. Seattle, WA: U.S. Environmental Protection Agency, Region 10.

United States Environmental Protection Agency (EPA) (2014). Columbia River Toxics Reduction Working Group: Strategy For Measuring, Documenting and Reducing Chemicals of Emerging Concern. Seattle, WA: U.S. Environmental Protection Agency.

United States Geological Survey (USGS) (2017). Contaminants of Emerging Concern in the Environment Retrieved from https://toxics.usgs.gov/investigations/cec/index.php.

Washington State Department of Ecology (2017). Columbia River Facts and Maps. Retrieved from http://www.ecy.wa.gov/programs/WR/cwp/cwpfactmap.html.

Washington Toxics Coalition (2006). Pollution in People: A Study of Toxic Chemicals in Washingtonians. Retrieved from http://pollutioninpeople.org/files/pollutioninpeople_may06.pdf.

West Multnomah Soil and Water Conservation District (2014). Sauvie Island Soil Map Retrieved from https://wmswcd.org/wp-content/uploads/2015/12/Sauvie-Island-Soils-Map.pdf?f3148f. 